6. Lin F, Haiyan Liu. Immunohistochemistry in Undifferentiated Neoplasm / Tumor of Uncertain Origin. Arch Pathol Lab Med. 2014;138:1583-610.

7. Federico Coccolini, Federico Gheza, Marco Lotti, Salvatore Virzì, Domenico Iusco, Claudio Ghermandi,
Rita Melotti, Gianluca Baiocchi, Stefano Maria Giulini, Luca Ansaloni, and Fausto Catena. Peritoneal carcinomatosis. World J Gastroenterol. 2013;19(41):6979-94.

8. Vajdic CM, Goldstein D. Cancer of unknown primary site. Aust Fam Physician. 2015;44(9):640-643.

Стаття надійшла до редакції 26.07.2018

\title{
O.A. Rosits'ka \\ EVALUATION OF THE CHARACTER OF STRUCTURAL AND FUNCTIONAL CHANGES IN CEREBRAL VESSELS IN PATIENTS WITH ISCHEMIC CEREBROVASCULAR DISEASES ON THE BACKGROUND OF MULTIFOCAL LESIONS
}

\author{
SE «Dnipropetrovsk medical academy of Health Ministry of Ukraine» \\ Department of Family Medicine of Postgraduate Education Faculty \\ V. Vernadsky str., 9, Dnipro, 49044, Ukraine \\ ДЗ «Дніпропетровська медична академія МОЗ Украӥни» \\ кафедри сімейної медицини ФПО \\ (зав. - д. мед.н., доц. І.Л. Височина) \\ вул. В. Вернадського, 9, Дніпро, 49044, Украӥна \\ e-mail:aleksa2005@ua.fm
}

Key words: ischemic impairment of cerebral circulation, abnormal deformation of the internal carotid and vertebral artery, stenosing lesions of the internal carotid and vertebral artery

Ключові слова: ішемічні порушення мозкового кровообігу, патологічна деформація внутрішньої сонної артерії та хребтової артерї, стенозуюче ураження внутрішньої сонної артерії та хребтової артерії Ключевые слова: ишемические нарушения мозгового кровообращения, патологическая деформация внутренней сонной артерии и позвоночной артерии, стенозирующем поражения внутренней сонной артерии и позвоночной артерии

\begin{abstract}
Evaluation of the character of structural and functional changes in cerebral vessels in patients with ischemic cerebrovascular diseases on the background of multifocal lesions. Rosits'ka O.A. The hemodynamic consequences of brain damage depend on the state of the autoregulation system of the cerebral circulation, on the severity, prevalence and rate of progression of the atherosclerotic process (one or more basins), changes in the vascular wall, and the features of the anatomical structure of the cerebral vascular system. Most registries cannot determine the cause of stroke in 25-40\% of patients - the so-called cryptogenic strokes. Therefore, the question of underestimation of such disorders as tortuosity, extravasal compression, anomaly of development of not only internal carotid arteries, but also vertebral and subclavian arteries in the diagnosis of the effect on the course of cerebral ischemia is raised. In high-risk groups, the effect of pathology in the carotid arteries on the course of cerebral vascular disease is more often compared with the data of similar changes in extracranial vertebral arteries. In the general group of patients with multifocal lesion of the vessels (MFLV), tortuosity of blood vessels were found in the basins of the
\end{abstract}


internal carotid artery (ICA) and vertebral artery (VA), and the frequency of deformations of the vessels of the vertebrobasilar basin predominated over the deformations in the carotid basin. Atherosclerotic lesions of the vessels of the BA (basilar artery) and VA pools were less frequent than the carotid, but more pronounced. Atherosclerotic lesions of the subclavian artery (Left subclavian artery) are significantly more frequent in the group of patients with vascular lesions of the heart, brain and lower limbs. According to the data of the correlation analysis, possible associations of atherosclerotic vascular lesions of the main arteries of the head (MAH) are established, both among them and with other risk factors.

Реферат. Оцінка характеру структурних та функціональних змін судин головного мозку у хворих 3 ішемічними цереброваскулярними захворюваннями на тлі мультифокального ураження. Росицька О.А. Гемодинамічні наслідки ураження мозку залежать від стану системи ауторегуляції мозкового кровообігу, від тяжкості, поширеності і темпів прогресування атеросклеротичного процесу (одного чи декількох басейнів), змін судинної стінки, особливостей анатомічної будови судинної системи мозку. Більшість реєстрів не можуть визначити певну причину інсульту в 25-40\% хворих - так звані криптогенні інсульти. Тому ставиться питання щьодо можливості недооцінки при діагностиці впливу на перебіг ішемї мозку таких порушень, як звивистість, екстравазальна компресія, аномалія розвитку не тільки внутрішніх сонних артерій, a $i$ хребтових, підключичних артерій. У групах підвищеного ризику частіше аналізують вплив патології в сонних артеріях на перебіг судинних захворювань мозку порівняно з даними щуодо аналогічних змін в екстракраніальних хребетних артеріях. У загальній групі хворих з МФУС звивистість судин зустрічалась у басейнах ВСА $і$ ХА, причому частота деформацій судин вертебрально-базилярного басейну домінувала над деформаціями в каротидному басейні. Атеросклеротичне ураження судин басейнів БА і ХА було менш частим порівняно 3 каротидним, але більш вираженим. Атеросклеротичні ураження підключичної артерії (ЛПідключ.А) вірогідно частіше зустрічаються в групі пацієнтів з ураженням судинних басейнів серия, мозку та нижніх кіниівок. За даними кореляційного аналізу встановлено вірогідні асоціаџіï атеросклеротичного ураження судин основних МАГ як між собою, так $і$ з іншими чинниками ризику.

Atherosclerosis of the cerebral arteries is responsible for almost half of all brain cerebral infarctions, one of the main causes of chronic cerebrovascular disorders, but it may also be clinically "dumb" [2]. Innovative studies of carotid limb showed its prevalence ranging from $5 \%$ to $25 \%$ in patients with cerebrovascular symptoms or with asymptomatic carotid stenosis, which was diagnosed accidentally [6].

Markers of atherosclerosis is a thickening of intima-media complex( IMC) and the presence of plaques in the common carotid artery (CCA). Thickening IMC mainly represents the adaptive hypertrophic response of smooth muscle cells in the middle membrane to significant hemodynamic shock. Plaques usually occur in areas of low hemodynamic shock and not laminar turbulent blood flow, such as onion of carotid artery and proximal internal carotid artery (ICA), at least in the distal CCA. Plaques and IMC could be a different phenotypes of atherosclerosis with different connections with cardiovascular risk factors and clinical vascular disease [7].

The expressiveness of the atherosclerotic lesion of the major arteries of the head does not always directly affect the incidence of ischemic cerebrovascular accidents (ICVA). The possibility of acute ICVA is largely determined by the state of the cerebral vascular reserve (CVR - the level of reactivity of the cerebrovascular vessels, which evaluates their ability to further increase blood circulation). Preservation of the CVR provides the functional stability of the whole system of cerebral circulation. In the CVR there are anatomical (connecting arteries of the circle of Willis, leptomeningeal and ophthalmic anastomoses, as well as directly the cerebral arteries) and functional (autoregulatory mechanisms of the brain blood circulation system) source of compensation. Deterioration of the CVR may be considered as a predictor of cerebral hemodynamic dysfunction [5].

The hemodynamic effects of atherosclerotic lesion of MAH depend on their severity and the prevalence of the process, the peculiarities of the anatomical structure of the vascular system of the brain, the rates of progression of the atherosclerotic process, as well as on the state of the system of autoregulation of the cerebral circulation [5].

Among the causes of chronic and acute cerebrovascular disorders, which determine the state of hemodynamics, is the pathological deformation of the BCA. The overall frequency of abnormal deformations of the ICA, according to data from dopplerographic, angiographic or pathoanatomical studies, varies within $10-40 \%$ of the adult population $[1,6]$ (without a history of atherosclerosis, diabetes or hypertension).

There is a lack of data on the impact of extracranial vertebral arteries on the course of vascular diseases of the brain, as compared to publications on similar changes in carotid arteries in high-risk groups. Most registries cannot determine the cause of a stroke in $25-40 \%$ of patients - the so-called 
cryptogenic stroke. Pathology of vessels in extracranial vertebral arteries (segments V0-V3) remains one of the possible causes of cryptogenic stroke, where the severity and the presence of clinical symptoms in general can be very diverse and inconceivable [8].

The study of the peculiarities of the distribution of atherosclerotic plaques in the basins of the brain, the discovery of some patterns of atherosclerotic lesion and pathological deformation of the arteries of the brain will contribute to more precise planning of diagnostic and therapeutic measures, improvement of the prognosis of the course of clinical vascular diseases in patients with multifocal lesion of vessels (MFLV).

To study the character of the structural and functional characteristics of the vessels of the brain (extra-intracranial) according to Doppler ultrasonography and selective cerebral angiography (SCA) in patients with ischemic cerebrovascular diseases against the background of multifocal vascular lesion.

\section{MATERIALS AND METHODS}

The study included 125 patients aged 40 to 84 years with multifocal lesion of the vessels (MFLV). Depending on the localization of vascular basin defeat by stenotic atherosclerosis, all patients were divided into three clinical groups: I group - 19 $(15.2 \%)$ patients with lesion of the vessels of the brain, heart and lower limbs; group II - 87 (69,6\%) patients with a lesion of vessels of the brain and heart; group III - $19(15.2 \%)$ of patients with lesion of the vessels of the brain and lower limbs. Of these, $101(80.8 \%)$ are males and $24(19.2 \%)$ are female. The average age of patients was $(62.9 \pm 0.79)$ years.

Evaluation of the neurological status was carried out with the identification of leading clinical symptoms and the establishment of a form of cerebral circulation disorder. The character of the vascular lesion was clarified with the help of Doppler ultrasonography of the main extra- and intracranial arteries on the device SONOS-1000 of Hewlett-Packard Company (USA), as well as selective cerebral angiography (according to indications). Structural lesions and their degree were determined with the help of MRI of the brain on the apparatus of the company "General Electric" (USA).

Statistical analysis of the obtained data was carried out using the licensed program Statistica v.6.1®. The hypothesis of a normal distribution law for quantitative data was verified by the Kolmogorov-Smirnov criterion with the Liliefors amendment. Under normal distribution, the quantitative indicators are presented as the mean and its standard error $(\mathrm{M} \pm \mathrm{m})$, in other cases the median and interquartile spread Me $(25 \%, 75 \%)$ are given. Compa- rison of the average indicators in the clinical groups was carried out according to the appropriate Student (t) and Mann-Whitney (U) criteria, the relative indices were based on the Pearson Chi-square test $\left(\chi^{2}\right)$ and the exact Fisher test. The relationship between the individual factors was evaluated using the Spearman rank correlation coefficient $\left(\mathrm{r}_{\mathrm{s}}\right)$.

\section{RESULTS AND DISCUSSION}

The analysis of the results of Doppler ultrasonography and SCA in patients with ICD showed a high incidence of stenosing defeat of the main vessels of the head (MAH), mostly in the carotid basin (Table 1). Almost all of the patients had lesions in the ICA basin (120 patients - 96.0\%), including $87.2 \%$ in left internal carotid artery (L ICA) and $84.8 \%$ in right internal carotid artery (RICA). Bilateral lesions of the ICA were observed in $95(76.0 \%)$ cases. At the same time, in the structure of the revealed disorders (215 cases in ICA), about half were hemodynamically significant stenoses $(50-99 \%)$ or occlusions ( 110 cases $-51,2 \%)$.

The atherosclerotic lesion of vessels in the basins of BA and VA was less frequent compared with carotid, but more pronounced (table 1). Most often stenotic disorders were observed in VA - $46(36.8 \%)$ patients, of which $28.0 \%$ of cases in LVA, $22.4 \%$ in RVA, $13.6 \%$ - in both basins at the same time. In 46 of $71(64.8 \%)$ cases of atherosclerotic lesions of VA and BA basins were hemodynamically significant stenoses (34-47.9\%) and occlusion (12$16.9 \%$ ).

The analysis of stenosing lesion of the MAH in patients with clinical groups (fig. 1) showed that:

- in all groups, the vessels of the ICA basin reach a stenosing process with roughly the same frequency (78.9-89.5\%);

- LCCA is added to the stenosing process slightly more frequently in patients of group I $-31.6 \%$ vs. $19.5 \%$ in group II $\left(\mathrm{p}=0.249\right.$ for $\left.\chi^{2}\right)$ and $15.8 \%$ in group II $\left(\mathrm{p}=0.252\right.$ for $\left.\chi^{2}\right)$;

- atherosclerotic lesions of the subclavian artery (LSA) are more likely to occur in group I, than in II $-15.8 \%$ vs. $2.3 \%(p=0.039$ per FET $)$;

- the percentage of stenotic vascular lesion of the vertebrobasilar basin (VBB) in patients with atherosclerosis of the coronary, cerebral basins and lower extremities (group I) is more than twice as high as in patients with II and III groups (except for RVA in group III): for LVA $-52.6 \%$ in group I compared with $24.1 \%$ in group II $\left(p=0.013\right.$ for $\left.\chi^{2}\right)$ and $21.1 \%$ in group II $\left(\mathrm{p}=0.044\right.$ for $\left.\chi^{2}\right)$; for PCA $42.1 \%$ versus $17.2 \%\left(\mathrm{p}=0.017\right.$ for $\left.\chi^{2}\right)$ and $26.3 \%$ $\left(\mathrm{p}=0.305\right.$ for $\left.\chi^{2}\right)$. 
Degree of atherosclerotic lesion of MAH in patients with MFLV (n/\%)

\begin{tabular}{|c|c|c|c|c|c|c|c|}
\hline \multirow{2}{*}{ Basin of the MAH } & \multirow{2}{*}{$\begin{array}{l}\text { Number of } \\
\text { cases }\end{array}$} & \multicolumn{6}{|c|}{ Degree of atherosclerotic lesion of the MAH } \\
\hline & & $<\mathbf{2 9 \%}$ & $30-49 \%$ & $50-69 \%$ & $70-99 \%$ & occlusion & medium * \\
\hline \multicolumn{8}{|c|}{ Carotid basin } \\
\hline LICA & $109 / 87,2$ & $26 / 20,8$ & $28 / 22,4$ & $23 / 18,4$ & $12 / 9,6$ & $20 / 16,0$ & $50(30 ; 80)$ \\
\hline RICA & $106 / 84,8$ & $17 / 13,6$ & $34 / 27,2$ & $26 / 20,8$ & $15 / 12,0$ & $14 / 11,2$ & $50(30 ; 70)$ \\
\hline LCCA & $26 / 20,8$ & $9 / 7,2$ & $11 / 8,8$ & 2/1,6 & $4 / 3,2$ & - & $30(27 ; 44)$ \\
\hline RCCA & $16 / 12,8$ & $5 / 4,0$ & $9 / 7,2$ & 2/ 1,6 & - & - & $36(25 ; 42)$ \\
\hline Left ECA & $7 / \mathbf{5 , 6}$ & - & $4 / 3,2$ & $1 / 0,8$ & 2/ 1,6 & - & $40(35 ; 75)$ \\
\hline Right ECA & $5 / 4,0$ & - & - & 2/ 1,6 & $3 / 2,4$ & - & $70(50 ; 80)$ \\
\hline Left $\mathrm{ACA}^{* * *}$ & $1 / 1,1$ & - & - & - & $1 / 1,1$ & - & 75 \\
\hline Right ACA** & $3 / 3,3$ & - & $2 / 2,2$ & $1 / 1,1$ & - & - & $40(30 ; 50)$ \\
\hline Left MCA** & $1 / 1,1$ & - & - & - & $1 / 1,1$ & - & 70 \\
\hline Right MCA** & $3 / 3,3$ & - & $1 / 1,1$ & - & - & $2 / 2,2$ & $100(30 ; 100)$ \\
\hline
\end{tabular}

VA and BA basins

\begin{tabular}{|c|c|c|c|c|c|c|c|}
\hline BA & $2 / 1,6$ & - & - & - & $2 / 1,6$ & - & $80(70 ; 90)$ \\
\hline LVA & $35 / 28,0$ & $1 / 0,8$ & $10 / 8,0$ & $11 / 8,8$ & $5 / 4,0$ & $8 / 6,4$ & $55(40 ; 95)$ \\
\hline RVA & $28 / 22,4$ & $2 / 1,6$ & $11 / 8,8$ & $7 / \mathbf{5 , 6}$ & $5 / 4,0$ & $3 / 2,4$ & $50(32 ; 78)$ \\
\hline LSA & $6 / 4,8$ & - & $1 / 0,8$ & $1 / 0,8$ & $3 / 2,4$ & $1 / 0,8$ & $80(50 ; 90)$ \\
\hline
\end{tabular}

Notes: * - the data are presented as Me (25; 75 percentiles); ** - according to SCA in 89 patients, in other cases, according to Doppler ultrasonography and SCA in 125 patients.

According to the correlation analysis, there are likely associations of atherosclerotic lesion of the vessels of the MAH both between them, and with other risk factors. Thus, the presence of stenosis in LICA correlates with the frequency of cerebral infarcts $(\mathrm{rs}=0.25, \mathrm{p}<0.01)$, including repeat $(\mathrm{rs}=0.20$, $\mathrm{p}<0.05)$, the presence and severity of hypertension (HD) $(\mathrm{rs}=0.20, \mathrm{p}<0.05)$, thickening of IMC $(\mathrm{rs}=0.27$, $\mathrm{p}<0.01)$, lesion of LVA $(\mathrm{rs}=0.19, \mathrm{p}<0.05)$. In atherosclerosis of RICA, thickening of IMC is more common ( $\mathrm{rs}=0.24, \mathrm{p}<0.05)$, stenosing process in LVA ( $\mathrm{rs}=0.21, \mathrm{p}<0.05)$ and RVA $(\mathrm{r} s=0.23, \mathrm{p}<0.05)$. Atherosclerotic lesions of LCCA are also directly associated with the frequency of transient ischemic attacks (TIA) in LICA ( $\mathrm{rs}=0.22, \mathrm{p}<0.05)$, symmetric lesions of RCCA ( $r s=0.45, p<0.001)$ and presence of stenosis in Right ACA / Left ACA / Left MCA $(\mathrm{rs}=0.21, \mathrm{p}<0.05)$. The lesion of RCCA is often combined with a high risk of recurrence of brain infarctions $(r s=0.19, p<0.05)$, stenotic disturbances in LCCA $(\mathrm{rs}=0.45, \mathrm{p}<0.001)$ and Right MCA $(\mathrm{rs}=0.28, \mathrm{p}<0.01)$. In atherosclerotic lesion of vessels of the carotid basin, interconnected disorders in vessels of the basins of BA and VA are also correlated: the correlation coefficient between the presence of stenosis in LVA and LICA is $\mathrm{rs}=0.19$, $\mathrm{p}<0.05$, between LVA and RICA $-\mathrm{rs}=0.21, \mathrm{p}<0,05$, between RVA and RICA $-r=0.23, p<0,05$, between RVA and Left ECA - rs $=0.20, p<0,05$, between RVA and Right ECA - rs $=0.28, p<0,01$. With a brain infarctions in the vertebrobasilar basin, stenosis is more often associated with stenosis of the $\mathrm{BA}(\mathrm{rs}=0.27, \mathrm{p}<0.01)$. 


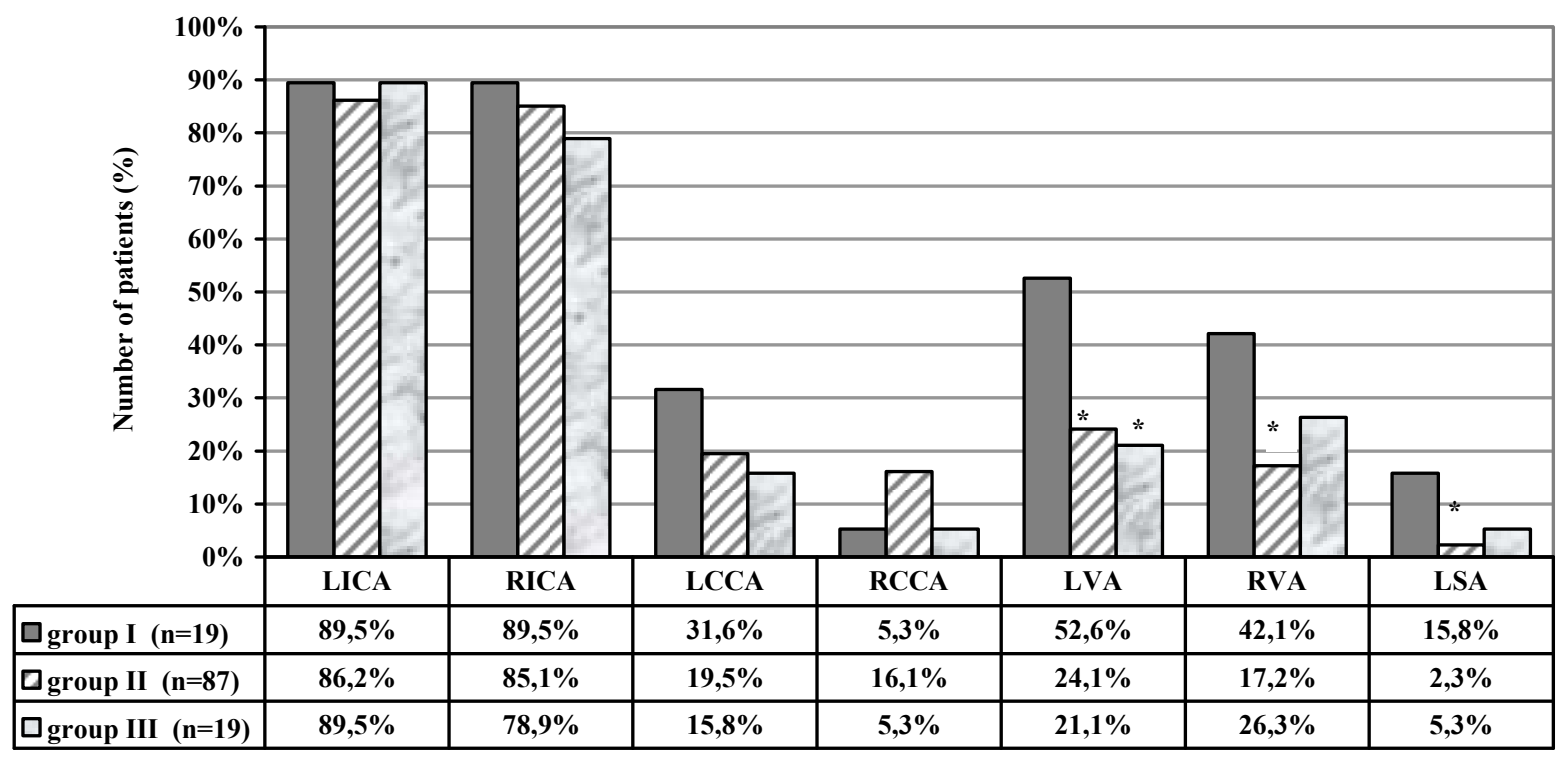

Fig. 1. Frequency of stenosing lesion of MAH in patients with clinical groups $(*-p<0,05$ in comparison with group I)

Taking into account that the pathological deformations of ICA and VA with more pronounced levels (according to the criteria of tortuosity of ICA for Weibel-Fields and Metz, [3]) occupy a special place among the causes of ischemic cerebrovascular disorders (according to various data - in $24 \%$ of patients, in the presence of atherosclerotic lesions of the carotid arteries, among patients with various vascular diseases, the tortuosity of the internal carotid artery is from $31 \%$ to $58 \%[3,4]$ ), we analyzed the frequency of deformations and anomalies of the development of vessels in the carotid and vertebrobasilar basins in a general group of patients with MFLV and in clinical groups (table 2, fig. 2).

In the general group of patients with MFLV, vascular tortuosity was observed in basins of ICA and VA, and the frequency of vascular deformities of the vertebral-basilar basin dominated the deformations in the carotid basin (in LVA and RVA $55.2 \%$ and $42.4 \%$, respectively, as compared to LICA and RICA - 24.8\% and 23.2\%; p $<0,01)$. Among spine arteries, deformity was more likely to be observed in the left VA - 55.2\% versus $42.4 \%$ in the right VA $\left(\mathrm{p}=0.043\right.$ for $\left.\chi^{2}\right)$. Pathological deformations in LICA and RICA were found in equal ratios (table 2). The correlation analysis data show the symmetry of the changes of the main vessels of the carotid basin, the coefficient of correlation between the deformation of LICA and RICA is $\mathrm{rs}=0.69, \mathrm{p}<0.001$, between LCCA and RCCA $\mathrm{rs}=0.34, \mathrm{p}<0.001$.

Table 2

\section{Frequency of deformations and anomalies of development of carotid arteries in patients with MFLV (n/\%)}

\begin{tabular}{cc|c|c}
\hline Basin of the MAH & Number of causes & Deformations & Anomalies \\
\hline LICA & $31 / 24,8$ & Carotid basin & - \\
RICA & $29 / 23,2$ & $31 / 24,8$ & - \\
LCCA & $2 / 1,6$ & $29 / 23,2$ & - \\
RCCA & $4 / 3,2$ & $2 / 1,6$ & - \\
\hline LVA & $4 / 3,2$ & - \\
RVA & $83 / 66,4$ & VA and BA basins & $7 / 5,6$ \\
\hline
\end{tabular}


In the analysis of the frequency of deformations / anomalies of ICA, VA in patients with clinical groups (fig. 2), the prevalence of disorders in patients of the group III was compared with the groups I and II: for LICA $-42.1 \%$ vs. $15.8 \%$ in group I $\left(\mathrm{p}=0.074\right.$ for $\left.\chi^{2}\right)$ and $23.0 \%$ for group II $(\mathrm{p}=0.087$ for $\left.\chi^{2}\right)$; for RICA $-42.1 \%$ vs. $10.5 \%(\mathrm{p}=0.027$ for $\left.\chi^{2}\right)$ and $21.8 \%\left(\mathrm{p}=0.066\right.$ for $\left.\chi^{2}\right)$; for bilateral lesion of VA $-73.7 \%$ vs. $42.1 \%\left(\mathrm{p}=0.049\right.$ for $\left.\chi^{2}\right)$ and $60.9 \%\left(\mathrm{p}=0.296\right.$ for $\left.\chi^{2}\right)$.
According to the results of the correlation analysis, the correlation between pathological deformations of ICA and VA and ischemic cerebrovascular accidents in patients with MFLV was established: between changes in RCCA and TIA in VBB $r s=0.27, p<0.01$, between deformations of LVA and repeated brain infarctions $-\mathrm{rs}=0,18, \mathrm{p}<0,05$, between the tortuosity of RICA and TIA in RICA $\mathrm{rs}=0,23, \mathrm{p}<0,05$.

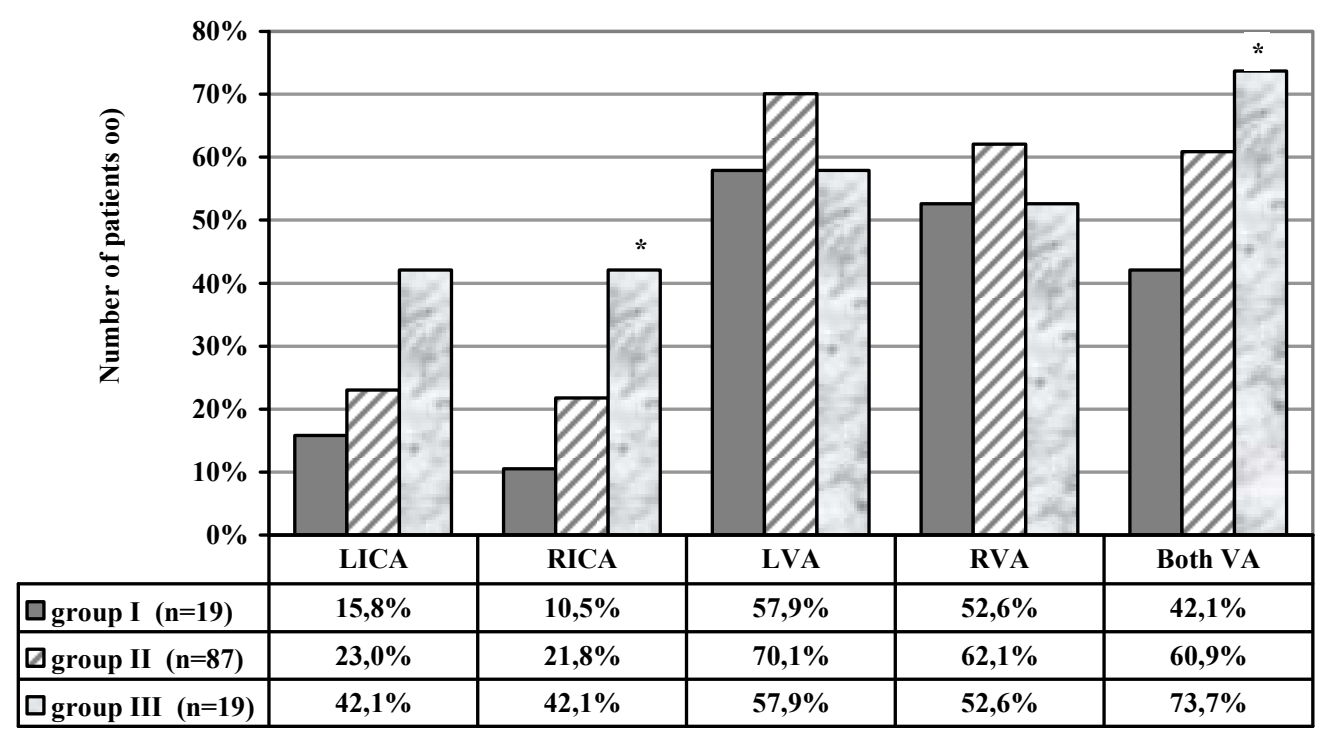

Fig. 2. Frequency of deformations / anomalies of main main arteries of the brain in patients with clinical groups: * $-\mathbf{p}<0,05$ in comparison with group $I$

\section{CONCLUSIONS}

4. In patients with ICD, a high incidence of stenosing lesion of the MAH is found, mostly in the carotid basin $-96.0 \%$, including $87.2 \%$ in LICA and $84.8 \%$ in RICA, of which about half are hemodynamically significant stenosis or occlusion $(51.2 \%)$;

5. Atherosclerotic vascular lesion of the basins of $\mathrm{BA}$ and VA is less frequently compared with carotid basin but is more pronounced (hemodynamically significant stenosis or occlusion $-64.8 \% ; \mathrm{p}<0.05$ );

6 . The percentage of stenotic vascular lesion in the vertebrobasilar basin in patients with group I is more than twice as high as in patients with II and III group (except for RVA in group III) at $\mathrm{p}<0.05$;

7. The frequency of vascular deformities in the vertebrobasilar basin dominates the pathological changes of the carotid basin vessels $(p<0.01)$ with the tendency to prevail such violations in patients of the group III;

8. Probable associations of atherosclerotic lesion of vessels of the MAH with each other as well as with ischemic impairment of cerebral circulation in patients with MFLV (brain infarctions, TIA, HD) were established.

\section{REFERENCES}

1. Kok GV, Agafonov PV, Kok BB. [Arterial hypertension and pathological tortuosity of carotid arteries]. Vestnik rossiyskoy voenno-meditsinskoy akademii. 2016;1:47-49. Russian.

2. Dubenko OE. [The role of intracranial atherosclerosis in the development of ischemic stroke: the comparative state of the problem]. Mizhnarodnyi nevrolohichnyi zhurnal. 2017;25-30. Russian.
3. Kopolovets I, Sihotski V, Frankovichova M. [Results of surgical treatment of vascular-cerebral insufficiency in patients with pathological morbidity of internal carotid arteries]. Kharkivska khirurhichna shkola. 2015;4:103-6. Ukrainian.

4. Kuzyk YuI. [Pathological convulsions of the internal carotid artery: morphological characteristics]. Patolohiia. 2014;2:100-3. Ukrainian. 
5. Sysun LA. [Possibilities of transcranial doppler examination for evaluation of cerebrovascular reserve of vessels of the brain]. Ukrainskyi radiolohichnyi zhurnal. 2014;34-37. Ukrainian.

6. Zenteno $\mathrm{M}$ et al. Clinical implications of internal carotid artery tortuosity, kinking and coiling: a systematic review. Romanian Neurosurgery. 2014;21(1):51-60.
7. Herder Marit et al. Risk factors for progression of carotid intima-media thickness and total plaque area: the Tromsø Study. Stroke. 2012;43(7):1818-23.

8. Bentsen L, Nygård A, Ovesen C, et al. Vascular Pathology in the Extracranial Vertebral Arteries in Patients with Acute Ischemic Stroke. Cerebrovascular Diseases Extra. 2014;4(1):19-27. doi: 10.1159/000357663

\section{СПИСОК ЛІТЕРАТУРИ}

1. Артериальная гипертензия и патологическая извитость сонных артерий / Г.В. Кок, П.В. Агафонов, Б.Б. Кок [та ін.]. // Вестник российской военномедицинской академии. - 2016. - № 1. - С. 47-49.

2. Дубенко О.Е. Роль интракраниального атеросклероза в развитии ишемического инсульта: сравнительное состояние проблемы / O.Е. Дубенко // Міжнар. неврологічний журнал. - 2017. - С. 25-30.

3. Кополовець I. Результати хірургічного лікування судинно-мозкової недостатності у хворих із патологічною звивистістю внутрішніх сонних артерій / І. Кополовець, В. Сіготські, М. Франковічова // Харківська хірургічна школа. - 2015. - № 4. - С. 103-106.

4. Кузик Ю.І. Патологічні звивистості внутрішньої сонної артерії: морфологічна характеристика / Ю.І. Кузик // Патологія. - 2014. - № 2. - С. 100-103.
5. Сисун Л.А. Можливості транс краніальної доплерографії для оцінки цереброваскулярного резерву судин головного мозку / Л.А. Сисун // Укр. радіологічний журнал. - 2014. - С. 34-37.

6. Clinical implications of internal carotid artery tortuosity, kinking and coiling: a systematic review / M. Zenteno [et al.] // Romanian Neurosurgery. - 2014. Vol. 21, N 1. - P. 51-60.

7. Risk factors for progression of carotid intimamedia thickness and total plaque area: a 13-year followup study: the Tromsø Study / Herder Marit [et al.] // Stroke. - 2012. - Vol. 43, N 7. - P. 1818-1823.

8. Vascular Pathology in the Extracranial Vertebral Arteries in Patients with Acute Ischemic Stroke / L. Bentsen, A. Nygård, C. Ovesen [et al.] // Cerebrovascular Diseases Extra.-2014.-Vol. 4, N 1.- P. 19-27. doi: 10.1159/000357663

Стаття надійшла до редакції 30.08 .2018

\section{B.A. Капустник, \\ ЗАЛЕЖНІСТЬ ЦИТОКІНЕМІї І.Ф. Костюк, А.Я. Меленевич ВІД КЛІНІЧНОГО ПЕРЕБІГУ ХРОНІЧНОГО ОБСТРУКТИВНОГО ЗАХВОРЮВАННЯ ЛЕГЕНЬ У ПОЄДНАННІ 3 ГІПЕРТОНІЧНОЮ ХВОРОБОЮ}

Харківський національний медичний університет

кафедра внутрішніх та професійних хвороб

вул. Трінклера, 6, Харків, 61022, Україна

Kharkiv national medical university

Department of internal and occupational diseases

Trinkler str., 6, Kharkiv, 61022, Ukraine

e-mail:occupdis@gmail.com

Ключові слова: хронічне обструктивне захворювання легень, гіпертонічна хвороба, системне запалення, біомаркери, інтерлейкін-18, інтерлейкін-10

Ключевые слова: хроническое обструктивное заболевание легких, гипертоническая болезнь, системное воспаление, биомаркеры, интерлейкин-18, интерлейкин-10

Key words: chronic obstructive pulmonary disease, hypertension, systemic inflammation, biomarkers, interleukin-18, interleukin-10 